\title{
Revision of Coptochilus (Heteroptera, Scutelleridae, Pachycorinae)
}

\author{
Luís Ricardo Schmitz' (1), Aline Barcellos ${ }^{1}$ (i) \& Joseph Eger ${ }^{2}$ (i)
}

\footnotetext{
1. Museu de Ciências Naturais, Secretaria do Meio Ambiente e Infraestrutura, Rua Dr. Salvador França, 1427, $90690-000$ Porto Alegre, RS, Brazil. (ricardoschmitz96@gmail.com; alinebar.fzb@gmail.com)

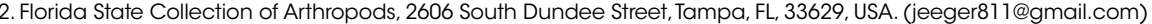

ABSTRACT. Coptochilus Amyot \& Serville, 1843 is distinguishable from the other Neotropical Scutelleridae by the dorsally concave head, with lateral margins of mandibular plates elevated. Here we describe and revise the species of Coptochilus based on general and genital morphological traits. Coptochilus castaneus (Dallas, 1851), once synonymous with C. ferrugineus Amyot \& Serville, 1843, is revalidated, and a new species, C. morrisi, is described from French Guiana. A key to the five species in the genus is provided.

KEYWORDS. Neotropics, new species, shield bug, revalidation, taxonomy.

Coptochilus was described by Амyot \& SeRviLle (1843) for Coptochilus ferrugineus Amyot \& Serville, 1843, based on material from Brazil. Other than the type species, the genus currently includes C. lentiginosus Berg, 1879 and C. neotropicalis (Distant, 1899), with type localities in Misiones, Argentina, and Amazonas, Brazil, respectively. The latter was described in the genus Achates Stål, 1867 and transferred to Coptochilus by EGER \& LATTIN (1997). Coptochilus castaneus (Dallas, 1851) was first described as Pachycoris castaneus and synonymized with $C$. ferrugineus by WALKER (1867).

EGER et al. (2015) listed Coptochilus species with distribution data and provided a key for the genera of neotropical Scutelleridae. Recently, the efferent system of the metathoracic gland of representatives of 21 genera of Pachycorinae, including $C$. ferrugineus, was analyzed under scanning microscopy and described (WeILER et al., 2017). The species of Coptochilus are distributed from Mexico to Argentina. The genus is distinguishable from other pachycorine genera by the head dorsally concave, with lateral margins of mandibular plates elevated. In this paper, we revise Coptochilus based on general and genitalic morphology, Coptochilus castaneus (Dallas, 1851) is revalidated, a new species is described and a key to its species is provided.

\section{MATERIAL AND METHODS}

The specimens belong to the following collections: American Museum of Natural History, New York, U.S.A. (AMNH); Carnegie Museum of Natural History, Pittsburgh, U.S.A. (CMNH); Coleção Entomológica "Adolph Hempel” of Instituto Biológico de São Paulo, São Paulo, Brazil (IBSP); David A. Rider personal collection (DAR), North Dakota, U.S.A; Donald B. Thomas personal collection (DBTC), Texas, U.S.A; Florida State Collection of Arthropods, Gainesville, U.S.A. (FSCA); Instituto Nacional de Biodiversidad, Heredia, Costa Rica (INBio); Joseph E. Eger personal collection (JEEC), Florida, E.U.A; Instituto Nacional de Pesquisas da Amazônia, Manaus, Brazil (INPA), Museo de La Plata, La Plata, Argentina (MLPA); Museo Nacional de Historia Natural del Paraguay, San Lorenzo, Paraguay (IBNP); Museu de Ciências Naturais, Secretaria do Meio Ambiente e Infraestrutura (formerly Museu de Ciências Naturais, Fundação Zoobotânica do Rio Grande do Sul), Porto Alegre, RS, Brazil (MCNZ); Museu Paraense Emílio Goeldi, Belém, Brazil (MPEG); Natural History Museum, London, UK (BMNH); Royal Belgian Institute of Natural Sciences, Brussels, Belgium (RBINS); Universidad Nacional Autónoma de México, Ciudad de Mexico, Mexico (UNAM); United States National Museum of Natural History, Washington D.C., U.S.A. (USNM); and Washington State University, M. T. James Entomological Collection, Pullman, U.S.A. (WSU). Type label data are presented as they appear on the labels; two or more labels are listed as a), b), etc. with a) being the label closest to the specimen. Specimens originating in one collection but transferred to a second collection are indicated by the abbreviation for the original collection and the second collection separated by a ".-".

The genitalia were cleared in a hot solution of $\mathrm{KOH}$ $10 \%$, dissected, and stained with Congo Red when needed. The male genitalia was expanded with forceps and entomological pins, but we were not always successful in obtaining expanded 
genitalia. The specimens were photographed with a Samsung J5 Prime attached to a Nikon SMZ800 stereomicroscope and with a Leica Z16 APO microscope using a JVC KY-F75U digital camera and stacked with Syncroscopy Automontage software, version 5.01.005. The photographs were edited with Adobe Photoshop $\mathrm{CS}^{\circledR}$ and drawings with Adobe Illustrator $\mathrm{CS}^{\circledR}$.

The terminology followed Tsai et al. (2011). Measurements (in $\mathrm{mm}$ ) were taken as follows: total length, from head apex to posterior margin of scutellum; length and width of head across eyes; length of anteocular region, from the apex of mandibular plates to anterior margin of the eyes; mesial length of pronotum; width of pronotum across humeri; mesial length of scutellum; greatest width of scutellum; length of abdominal segments medially. The distribution map was based on the biogeographical dominions by Morrone (2013) and the shape file made available by LÖWENBERG (2014).

\section{RESULTS}

\section{Coptochilus Amyot \& Serville, 1843}

Coptochilus Amyot \& Serville, 1843:XVII, 47 (key, description); DallaS, 1864:576; STÅL, 1864:47 (description); 1867:491 (keyed); WALKER, 1867:53 (catalog); MaYr, 1868:15 (key); STÅL, 1870:9 (catalog); BERG, 1879:26 (synonymy, distribution - Argentina); LeTHIERRY \& SEVERIN, 1893:33 (catalog); HaNDLIRSCH, 1900:131 (stridulation); Schouteden, 1904:44-46 (key, description); KirKaldy, 1903:230 (type); 1909:283 (catalog, synonymy); WeBER, 1930:75 (stridulation); BeCKer \& GraZia-VieIra, 1977:66; GraZia \& SCHWERTNER, 2011:12; EGER et al., 2015:783 (key); COSCARÓN, 2017:326-327 (distribution - Argentina); WeILER et al., 2017:30-31, 35 (external scent efferent system).

Type species: Coptochilus ferrugineus Amyot \& Serville, 1843, by monotypy (see KIRKALDY, 1903:230).

General shape and color (Figs 1-15). Body oval and somewhat rectangular, length $6.35-9.0 \mathrm{~mm}$. Color variable, usually shades of yellow or red with darker markings; thin impunctate line usually present mesially on pronotum and scutellum. Pronotum and scutellum forming an evenly convex profile, in lateral view. Ventral and dorsal surfaces regularly punctuate, except mesially on venter. Males are usually darker ventrally than females.

Head subquadrangular, mandibular plates concave dorsally, elevated laterally and anteriorly, surpassing to slightly shorter than clypeus (Figs 16-30). Rostrum reaching or slightly surpassing metacoxae, segment II longer than III and IV together, segment I, almost the same size as segment II (Figs 2, 5, 11,14). Antennal segment I longer than segment II; segment III 1.5x longer than segment II; segments IV and $\mathrm{V}$ subequal in length, fusiform and flattened, each one about twice as long as III; segments I-II cylindrical and III slightly flattened; segments III-V setose (Fig. 14).

Thorax. Pronotum almost twice as wide as it is long. Humeri not or slightly produced. Cicatrices slightly elevated and partially impunctate. Anterior margin of pronotum slightly sinuous, shallowly concave mesially. Anterolateral margins straight or slightly convex or concave. Posterolateral margins sinuous; posterior margin rectilinear (Figs 1, 4, 7, $10,13)$. Scutellum extending to the end of the abdomen in males, sometimes almost reaching the end of the abdomen in females; small fovea present, usually black. Coria exposed, reaching onto abdominal segment VI. Ostiole of metathoracic scent gland closer to metacoxa than to the lateral margin of metapleura. Ostiolar peritreme short, spout-like, directed laterally (WeILER et al., 2017). Sterna shallowly concave, prosternum more concave than meso- and metasternum, metasternum almost flat. Tibiae and ventral surface of femora with fine setae; coxae, trochanters, and basal half of femora usually lighter than the remaining leg segments, all segments uniformly light yellow in C. morrisi.

Abdomen (Figs 2, 5, 8, 11, 14). Posterolateral angles of sternites III-VI projected into small spines. Spiracles and trichobothria separated by a transverse depression on segments IV-VI, which is vestigial on VII. Sternite VII usually at least twice longer than VI mesially, almost twice longer in males of C. morrisi. Spiracles slightly darker than the surrounding surface, except in C. ferrugineus (Fig. 5) and C. morrisi (Fig. 11), in which they are hardly distinguishable from punctations.

Male genitalia (Figs 31-68). Pygophore globose, genital cup broadly open, dorsal and ventral rim both slightly concave, sinuous or subrectilinear (Figs. 31-45), apical third of ventral surface depressed (Fig. 76), proctiger rounded, poorly sclerotized. Parameres (pr) hook-like, apex turned laterad (Figs 46-50). Phallus (Figs 54-68). Basal plate poorly sclerotized, U-shaped; phallotheca barrel-shaped, mostly transparent, and poorly sclerotized; conjunctiva with three pairs of sclerotized processes. Conjunctival processes II and III (cpII, cpIII, respectively) mostly sclerotized except in C. neotropicalis (Figs 66-68); conjunctival processes III smaller than conjunctival processes II and the most lateral, even in expanded aedeagus, conjunctival processes II located laterally to aedeagus sensu stricto $(\mathrm{aed}=$ vesica). Conjunctival processes I (cpI) positioned behind aedeagus sensu stricto (vesica), wrinkled, entirely or mostly membranous, can be branched. Aedeagus sensu stricto large and subtrapezoidal, sclerotized except on apex, ventral margin of apex concave. When the phallus is expanded, the dorsal part of conjunctival process I, if present, is projected dorsally and the vesica ventrally (Figs 51-53).

Female genitalia (Figs 69-73). Valvifers VIII (vf8) subtriangular, sutural lines entirely or partially contiguous. Laterotergites VIII (1t8) subtriangular, spiracles not found, anterior margin of laterotergites IX (lt9) angled or convex, sutural lines parallel or subparallel. Tergite VIII not visible in ventral view. Valvifers IX (vf9) visible, mostly covered by the vf8. Gynatrium (Figs 74, 75): fecundation canal (fec) proximally " $T$ " shaped, distally cylindrical and sclerotized, hidden dorsally by a posteromedial pounch (pmgp) boneshaped. Spermathecal dilation (sd) elongate coming out of the distal part of the fecundation canal; distal ductus (dd) long, tapering until the proximal flange; proximal flange well developed; distal flange poorly developed, inconspicuous; 
apical receptacle (ar) irregularly cylindrical (Fig. 77), reniform (Fig. 78) or subrectangular (Fig. 79), always longer than intermediate part (ip).

Distribution (Fig. 80). Mexico (new record), Costa Rica (new record), Panama (new record), Colombia, French Guiana, Ecuador, Brazil, Bolivia, Paraguay, and Argentina.

Comments. Coptochilus is distinguished from other genera of Pachycorinae by the dorsally concave head, with lateral margins of mandibular plates elevated (EGER et al., 2015). The genus is restricted to the Neotropical region, and most of the species are related to one or two dominions proposed by MORrone (2013). Coptochilus castaneus is the most broadly distributed, ranging from Mexico to Bolivia.

\section{Key to the species of Coptochilus}

1. General color yellowish castaneous, with scattered black spots or darker longitudinal stripes on pronotum and scutellum (Figs 7, 10, 13) . . . . . . . . . . . 2

1'. General color dark reddish, black spots absent, darker longitudinal stripes, if present, confined to pronotum (Fig. 1) ....................

2. Longitudinal stripes distributed on pronotum and scutellum (Figs 10,13), anterior margin of laterotergites IX straight or almost straight (Figs 72,$73 ; 1$ t9) $\ldots \ldots \ldots \ldots . .3$

2'. Circular spots distributed irregularly on pronotum and scutellum (Fig. 7), anterior margin of laterotergites IX angled (Fig. 71: 1t9); widely distributed in Brazil with some records from French Guiana, Argentina, and Paraguay (Fig. 80) ........... C. lentiginosus

3. Mandibular plates longer than clypeus, converging apically, apices separated by less than width of second antennal segment (Fig. 25); conjunctival processes II acute; conjunctival processes-III well sclerotized, angled near base, apex rounded (Fig. 63); recorded only in French Guiana (Fig. 80) ............ C. morrisi sp. nov.

3'. Mandibular plates subequal to clypeus, apices not converging over apex of clypeus (Fig. 28); conjunctival processes II broad, apices rounded; conjunctival processesIII poorly sclerotized with apex acute (Fig. 66); distributed in Amazon Biome (South Brazilian Dominion sensu Morrone, 2013) (Fig. 80) .......... C. neotropicalis

4. Pronotum yellow to red, elongate macule along each lateral margin, impunctate (Fig. 1); abdominal sternite VII more than three times longer medially than VI in females, venter mostly yellowish to dark red, with darker areas on intersegments and small transverse bands laterally, posteriorly to spiracles (Fig. 2); distributed from Mexico to Bolivia (Mesoamerican Dominion and Pacific Dominion sensu stricto) (Fig. 80) . . . . . . . . . . C. castaneus

4'. Pronotum uniformly punctate, with some darker, vague longitudinal stripes (Fig. 4); abdominal sternite VII less than three times longer medially than VI in females, venter also reddish, darker laterally (Fig. 5); distribution restricted to Atlantic rainforest (Paraná Dominion sensu stricto) (Fig. 80) ................. C. ferrugineus

Coptochilus castaneus (Dallas, 1851), reval.

(Figs 1-3, 16-18, 31-33, 46, 54-56, 69, 77, 80)

Pachycoris castaneus DaLlas, 1851:35 (description, type locality Bolivia); DOHRN, 1859:3 (catalog); WALKER, 1867:53 (placed in synonymy of P. ferrugineus); BERG, 1879:26 (in part, synonymy, distribution Argentina); EgER \& LATTIN, 1997:414 (synonymy).

Coptochilus ferrugineus; WALKER, 1867:53 (in part, catalog, synonymy); STÅL, 1870:9 (in part, catalog, synonymy); LETHIERRY \& SEVERIN 1893:33 (in part, catalog); SCHOUTEDEN, 1904:92, 97 (in part, synonymy); KIRKALDY, 1909:283 (in part, catalog):43; EGER et al., 2015:761, 773, 782, fig. 23.7, 23.50 (in part, distribution, illustration). Coptocheilus ferrugineus; BERG, 1879:26 (bad spelling; in part, synonymy, distribution Argentina).

Medium-sized, color ferruginous to reddish with black punctuations uniformly distributed dorsally and laterally on venter. Pronotum with two large impunctate elongate yellow to red macules submarginally on anterolateral margins (Figs $1-3)$.

Head (Figs 16-18) dark yellow to red, clypeus, posterior, and lateral margins darker. Mandibular plates subequal in length to clypeus, rounded and slightly converging, but apices separated by more than the diameter of the second antennal segment, moderately elevated anteriorly (Fig. 16). Antenniferous tubercules and intersegments of antennal segments I-III concolorous with or lighter yellow than the remaining segments. Rostrum segment I, proximal portion of II, and joints of III and IV lighter yellow than or concolorous with the remaining segments.

Pronotum uniformly dark yellow to dark red, with darker, uniformly distributed punctation, longitudinal stripes not present or vague; impunctate macules usually lighter in color than surrounding surface; anterolateral margins of pronotum straight to slightly concave. Scutellum relatively uniformly dark yellow to dark red, immaculate, punctation generally dark red to black. Pleura mostly castaneus to yellowish, usually lighter along mesial and lateral margins and sterna. Legs. Coxa and adjacent surfaces of pleura, trochanter, and basal half of femur yellowish, remaining segments dark red to black.

Connexiva dark red to black, densely and concolorously punctate. Abdominal venter mostly red to yellowish, with darker areas on intersegmental sutures and pseudosutures (Fig. 2). Sternite VII in females more than three times longer than VI medially, more than 2.5 times longer than VI in males (Fig. 2).

Male genitalia. Pygophore (Figs 31-33). Ventral rim rectilinear to slightly concave (Fig. 31), strongly concave in posterior view (Fig. 33). Parameres crown highly curved, apex subtriangular (Fig. 46). Phallus (Figs 54-56). Conjunctival processes I surpassing conjunctival processes II and III, branched, ventral branch membranous except for a small acute tooth at apex, dorsal branch membranous and apically bilobed. Conjunctival processes II mostly sclerotized, curved at base and apex, broader than conjunctival processes III. 

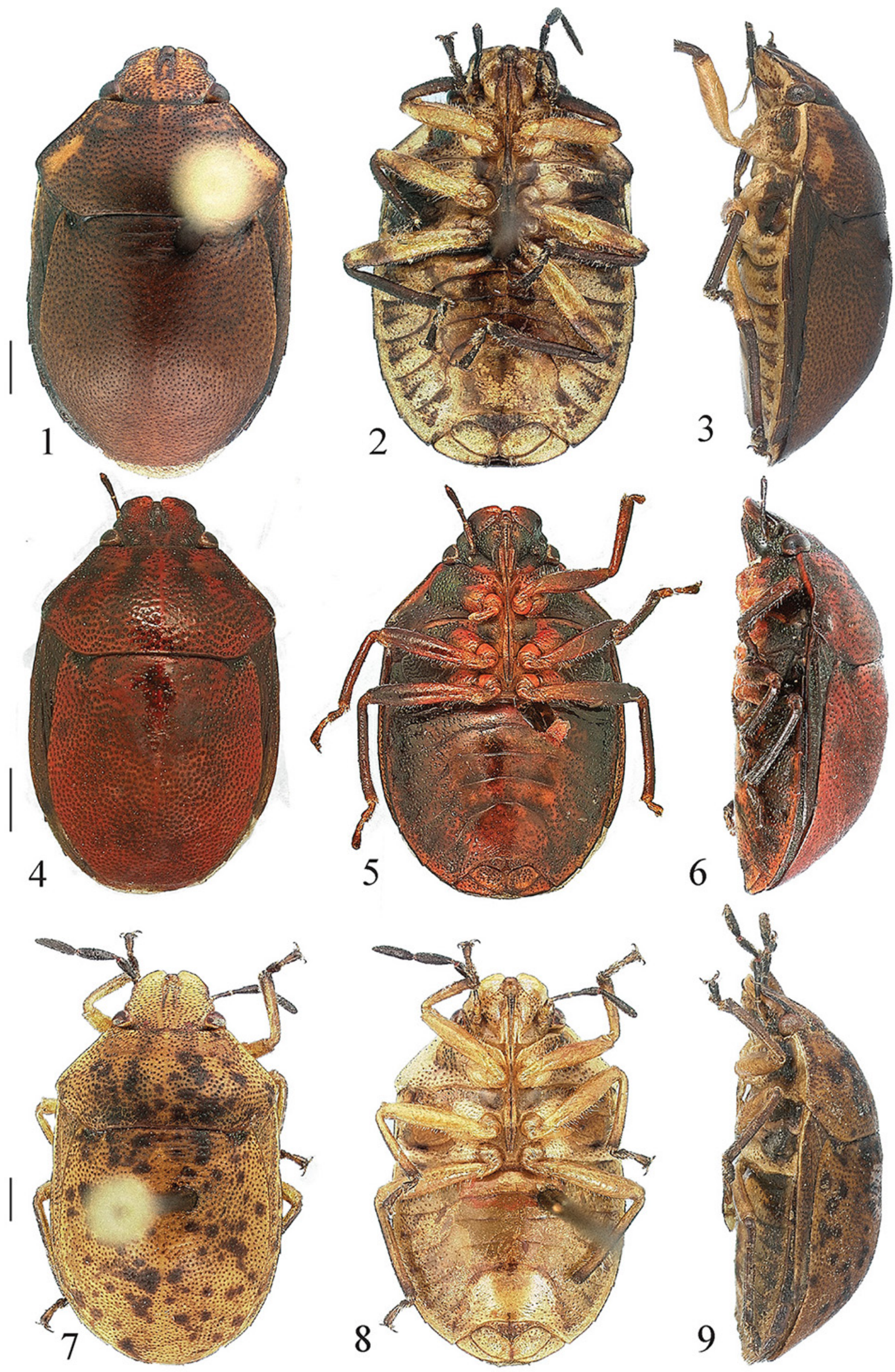

Figs 1-9. Coptochilus, habitus, respectively in dorsal, ventral, and lateral view: 1-3, C. castaneus (Dallas, 1851), reval.; 4-6, C. ferrugineus Amyot \& Serville, 1843; 7-9, C. lentiginosus Berg, 1879. Scale bars: $1.0 \mathrm{~mm}$. 


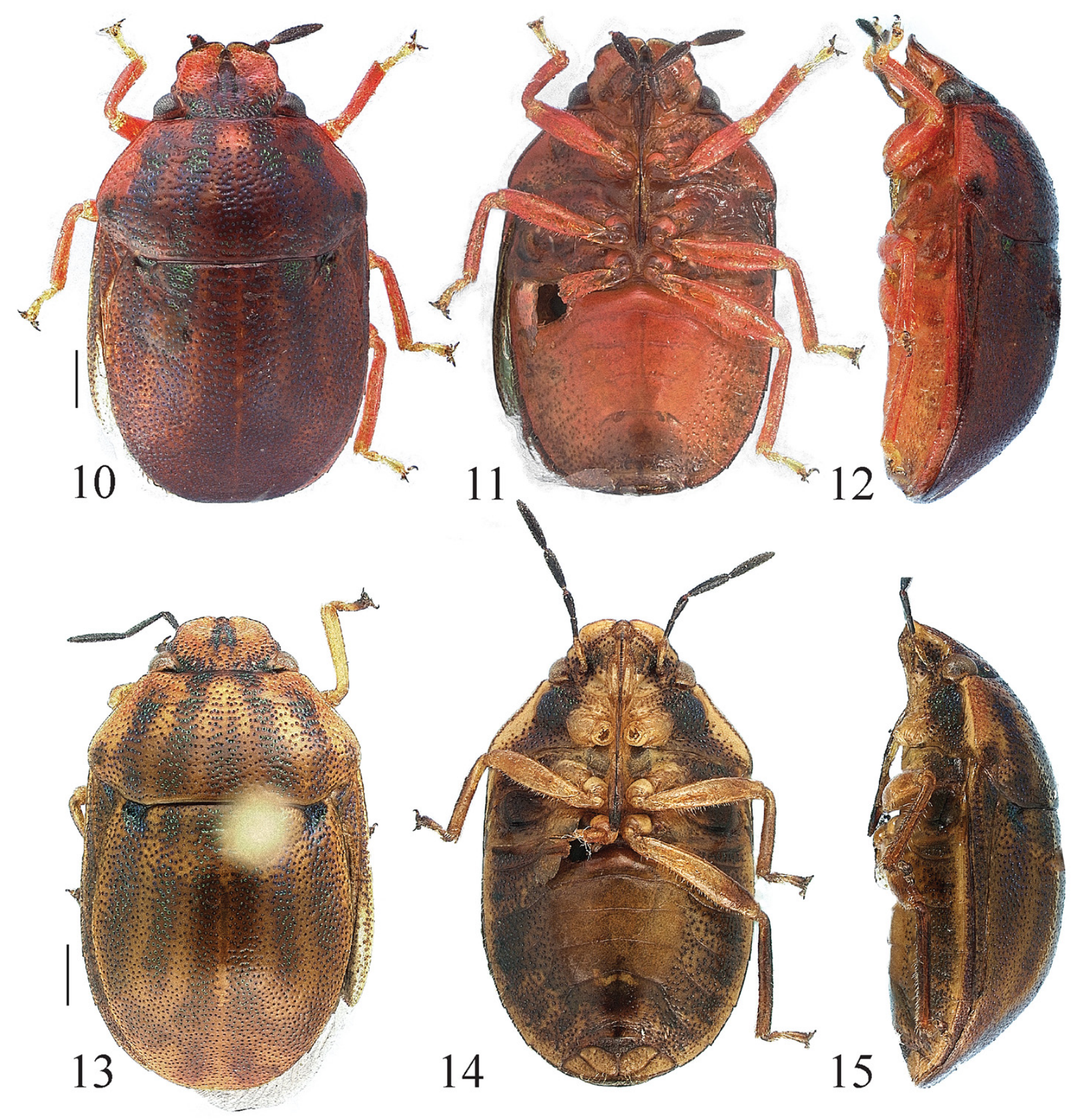

Figs 10-15. Coptochilus, habitus, respectively in dorsal, ventral, and lateral view: 10-12, C. morrisi sp. nov.; 13-15, C. neotropicalis Distant, 1899. Scale bars: $1.0 \mathrm{~mm}$.

Conjunctival processes III apex narrowly rounded and slightly curved, almost as long as conjunctival processes II. Distal part of aedeagus rectilinear, converging to broad apex, with margins rounded.

Female genitalia (Figs 69, 77). Laterotergite IX subtrapezoidal, anterior margin slightly angled (Fig. 69). Exposed portion of valvifers IX relatively short. Apical receptacle of spermatheca irregularly cylindrical, more than three times longer than the intermediate part (Fig. 77).

Male measures $(\mathrm{mm})(\mathrm{n}=10)$. Total length 7.00-8.10; head: length 1.60-1.90, width 2.20-2.50; preocular length $0.90-1.00$; pronotum: length $2.00-2.30$, width $4.30-4.90$; scutellum: length 4.20-4.85, width 4.05-4.85; length of sternite VI 0.40-0.50; length of sternite VII 1.20-1.50.

Female measures $(\mathrm{mm})(\mathrm{N}=11)$. Total length 8.00 8.80; head: length $1.50-1.95$, width $2.30-2.55$; length of anteocular region $0.80-1.00$; pronotum: length $2.00-2.50$, width 4.75-5.20; scutellum: length 4.85-5.50, width 4.505.00 ; length of sternite VI $0.30-0.45$; length of sternite VII $1.20-1.75$.

Type material. Holotype: female, labelled: a) Type [red circle], b) Bolivia, c) castaneus Dall., d) Pachycoris castaneus (type) Dallas, = Coptochilus ferrugineus $\mathrm{A} \& \mathrm{~S}$, e) BRIT. MUS., TYPE No, HEM. 552 (BMNH) (examined by the third author). 

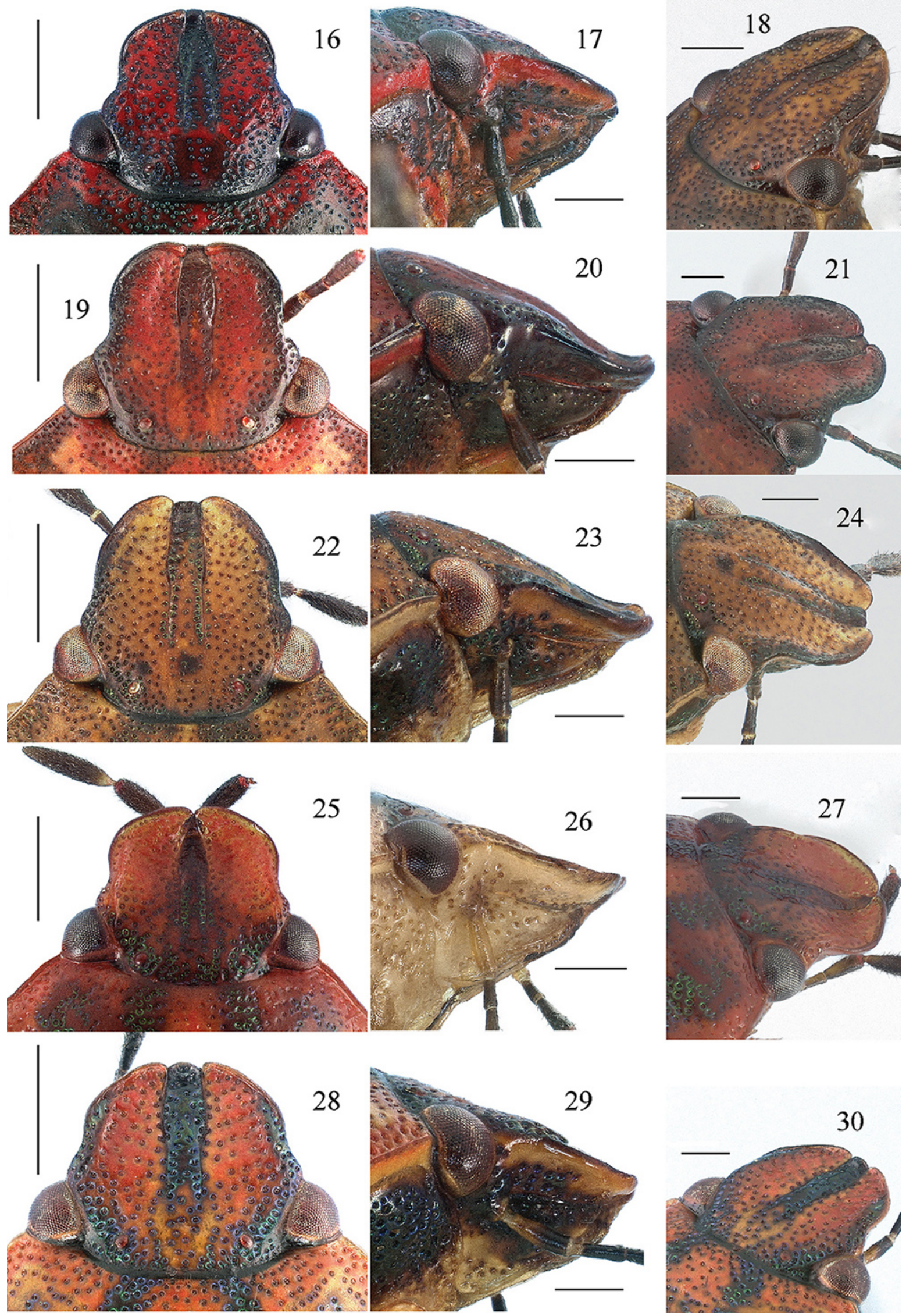

Figs 16-30. Coptochilus, head, respectively in dorsal, lateral, and dorsolateral view: 16-18, C. castaneus (Dallas, 1851), reval.; 19-21, C. ferrugineus Amyot \& Serville, 1843; 22-24, C. lentiginosus Berg, 1879; 25-27, C. morrisi sp. nov.; 28-30, C. neotropicalis Distant, 1899 . Scale bars: 1.0 mm. 

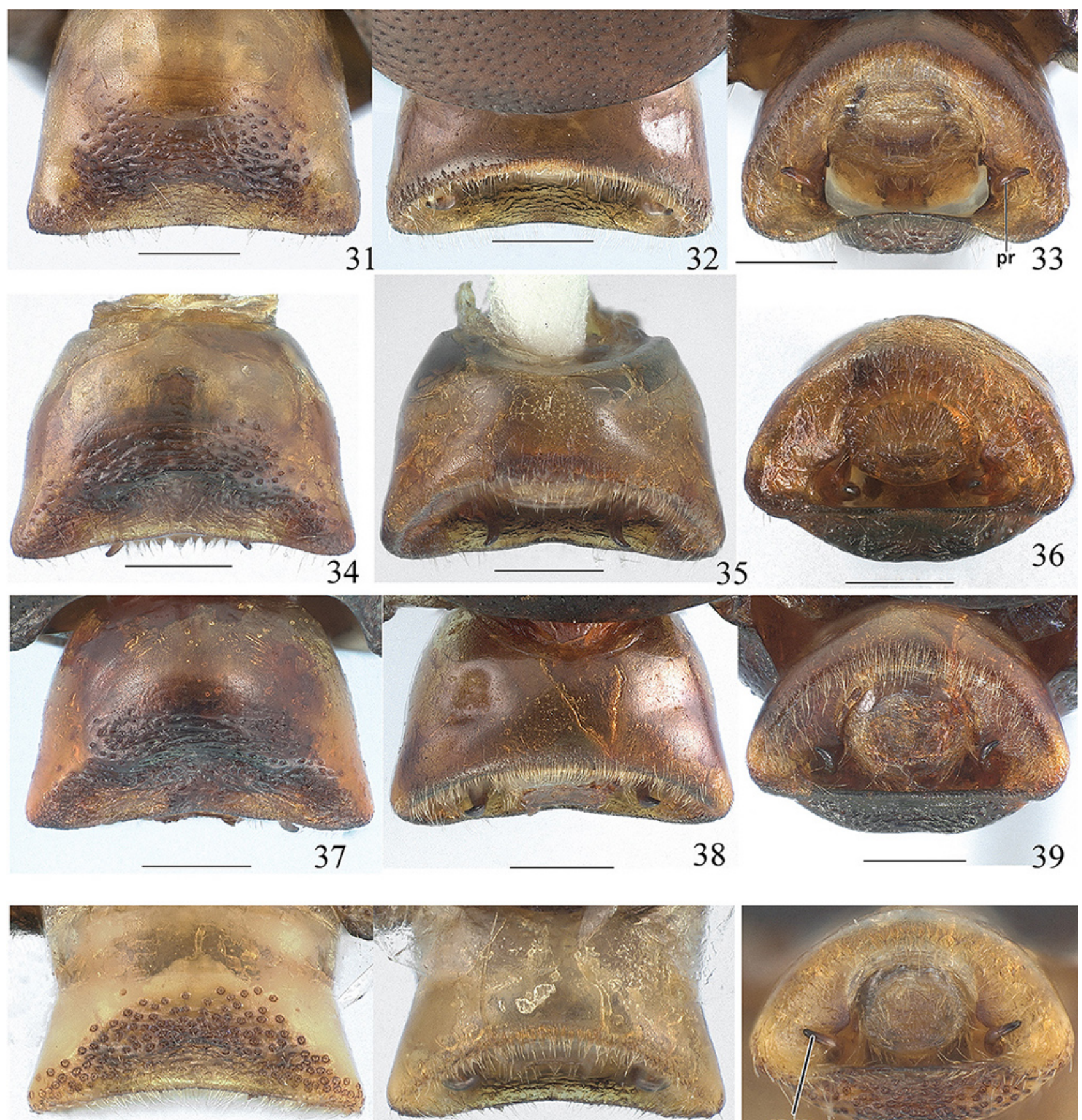

40

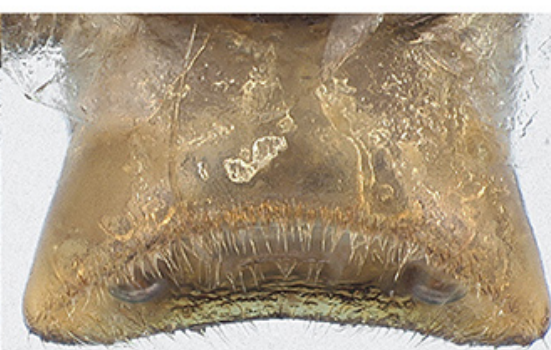

41

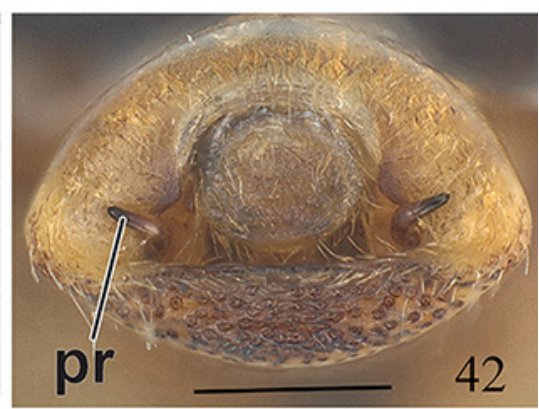

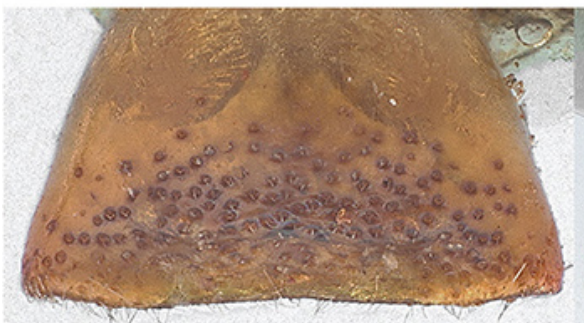

43

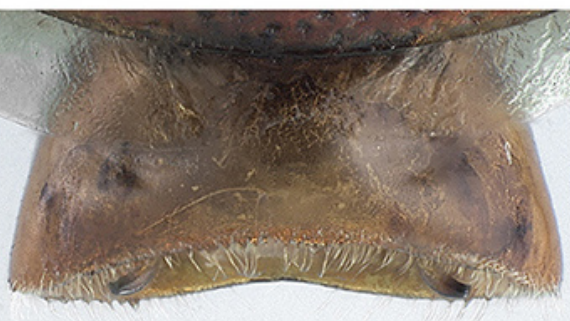

44

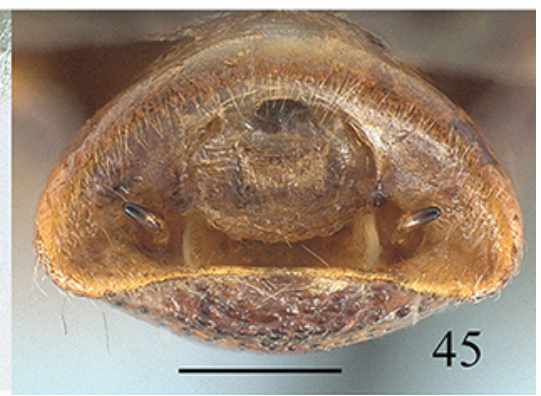

Figs 31-45. Coptochilus, pygophore, respectively in ventral, dorsal, and posterior view: 31-33, C. castaneus (Dallas, 1851), reval.; 34-36, C. ferrugineus Amyot \& Serville, 1843; 37-39, C. lentiginosus Berg, 1879; 40-42, C. morrisi sp. nov.; 43-45, C. neotropicalis Distant, 1899 (pr, parameres). Scale bars: $0.5 \mathrm{~mm}$. 

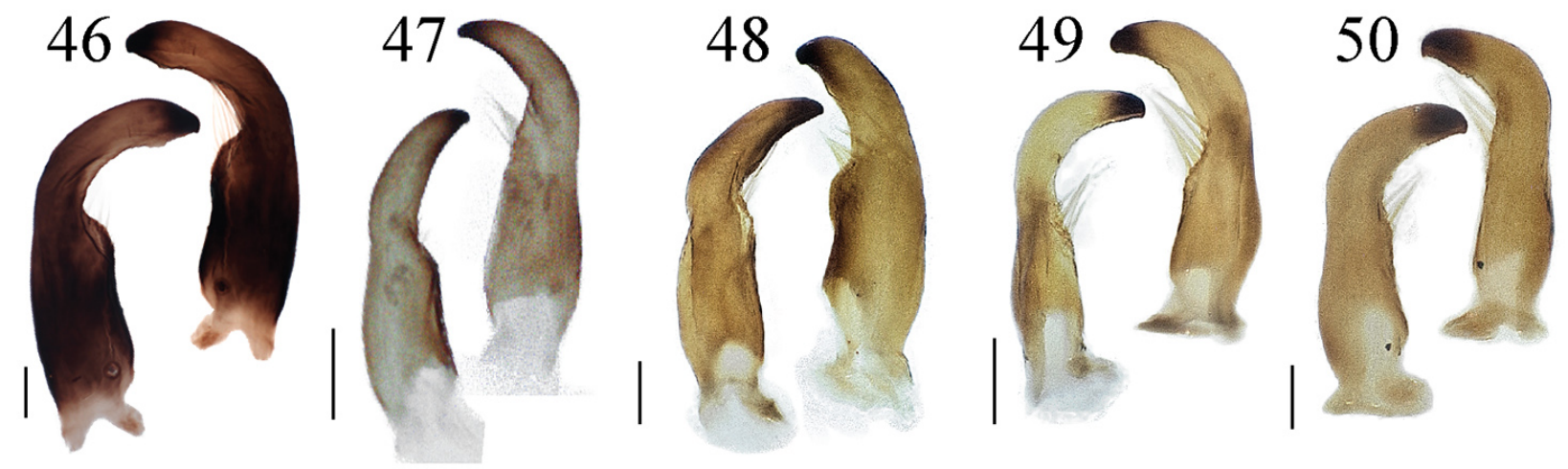

Figs 46-50. Coptochilus, right parameres, dorsal and ventral view: 46, C. castaneus (Dallas, 1851), reval.; 47, C. ferrugineus Amyot \& Serville, 1843; 48, C. lentiginosus Berg, 1879; 49, C. morrisi sp. nov.; 50, C. neotropicalis Distant, 1899. Scale bars: $0.1 \mathrm{~mm}$.

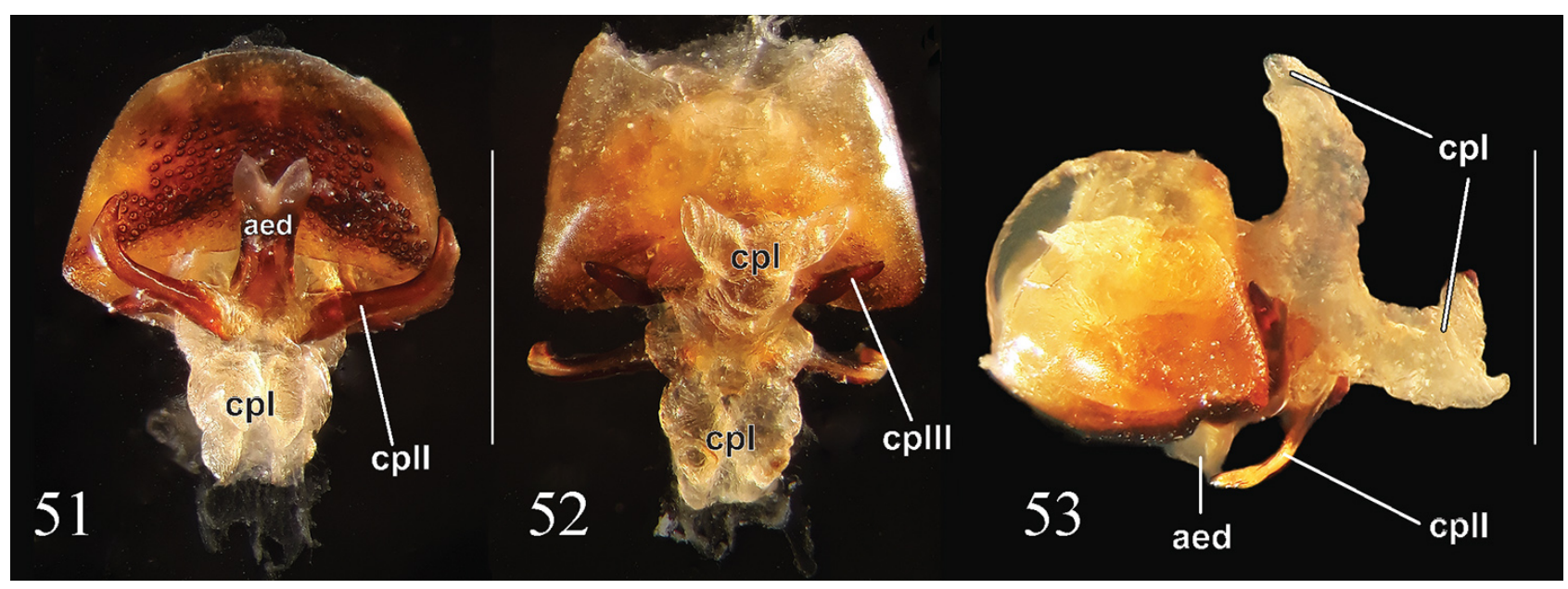

Figs 51-53. C. ferrugineus Amyot \& Serville, 1843, pygophore with phallus expanded, respectively in ventral, dorsal, and lateral view (aed, aedeagus; cpI, conjunctival process I; cpII, conjunctival process II; cpIII, conjunctival process III). Scale: $1.0 \mathrm{~mm}$.

Other material examined. MEXICO, Veracruz: Los Tuxtlas, ô, ㅇ, 27.XII.1985, C. Mayorga (UNAM); ô $^{\circ}+$, same data except L. Cervantes (UNAM). COSTA RICA, Guanacaste: Liberia (Parque Nal. Rincon de la Vieja, alt 020, scu-013), , 23.XI.1987, Lezama H. J. e Soto J. (MUCRJEEC); Alajuela: San Ramón Oeste (620 m), ㅇ, 3-19. IV.1994, Cano C. (LN318100_381900 \#2818) (INBIOJEEC); Heredia:Finca La Selva (3 km. S. Pto. Viejo), + , 29-31.VII.1976, Fisher E. M. (DBTC); San José: San José - Escazú, + , I.1988, Parker F. D. (DBTC). PANAMÁ, Colón, Fort Sherman (Canal Zone), 2犬̂, o , 13.X.80, Engleman D. col., D. H. Engleman Collection (JEEC); Cativá (Canal Zone, Coco Solo Hospital, 9`21'N 7951’W), ô, 8.V.74, Engleman (JEEC); Panamá: Ancón, đ̂, 9.IV.1926, CT Greene col., Coptochilus ferrugineus A. \& S., det. RISailer (USNM); Los Santos;Taboga,, , XII.1953, Krausa N. H. L. (AMNH_IZC 00319564). COLOMBIA, Magdalena: Río Frío (2000-2700 feet), ふ̊, 26.VII.1926, Walker F. W. (AMNH_IZC 00319557); same data, 우 (AMNH_IZC 00319558); same data, 우 (FSCA); Villavicencio, ㅇ, 3.XI.44, Hambleton E. J., Lot
No 44-28047 (USNM). ECUADOR, Napo: Napo (Puerto), +, 17.VI.1984, Haswell R. (WSU); Misahualli (Puerto, $1^{\circ} 2^{\prime} 4.2^{\prime} \mathrm{S}, 77^{\circ} 39^{\prime} 49.2^{\prime \prime} \mathrm{W}, 1650-1900 \mathrm{ft}$, mercury vapor \& ultraviolet lights), 2ð, 6-19.IX.1998, Eger J. E. (JEEC); đ, same locality, beating (JEEC); Orellana: Pompeya on Napo, Ô, 13.V.1965, Pena L. E. (AMNH_IZC 00319559); same data, $ᄋ$ (AMNH_IZC 00319560); BOLIVIA, Santa Cruz: Buena Vista (vic. Flora \& Fauna Hotel), §̂, 22-26.X.[20]02, Morris/Wappes (JEEC); Potosí: Sara, ô, no date, Steinbach (AMNH_IZC 00319562); same data, 2ㅇ (AMNH_IZC 00319561; 00319563).

Distribution. Mexico, Costa Rica, Panamá, Colombia, Ecuador, and Bolivia (Fig. 80).

Comments. This species, previously considered a junior synonym of $C$. ferrugineus, is here revalidated based on the longitudinal impunctate yellow to red macules along each lateral margin of pronotum, the different proportion of the median length of sternites VI and VII (males and females), the shape of the conjunctival processes and also the distribution pattern. 

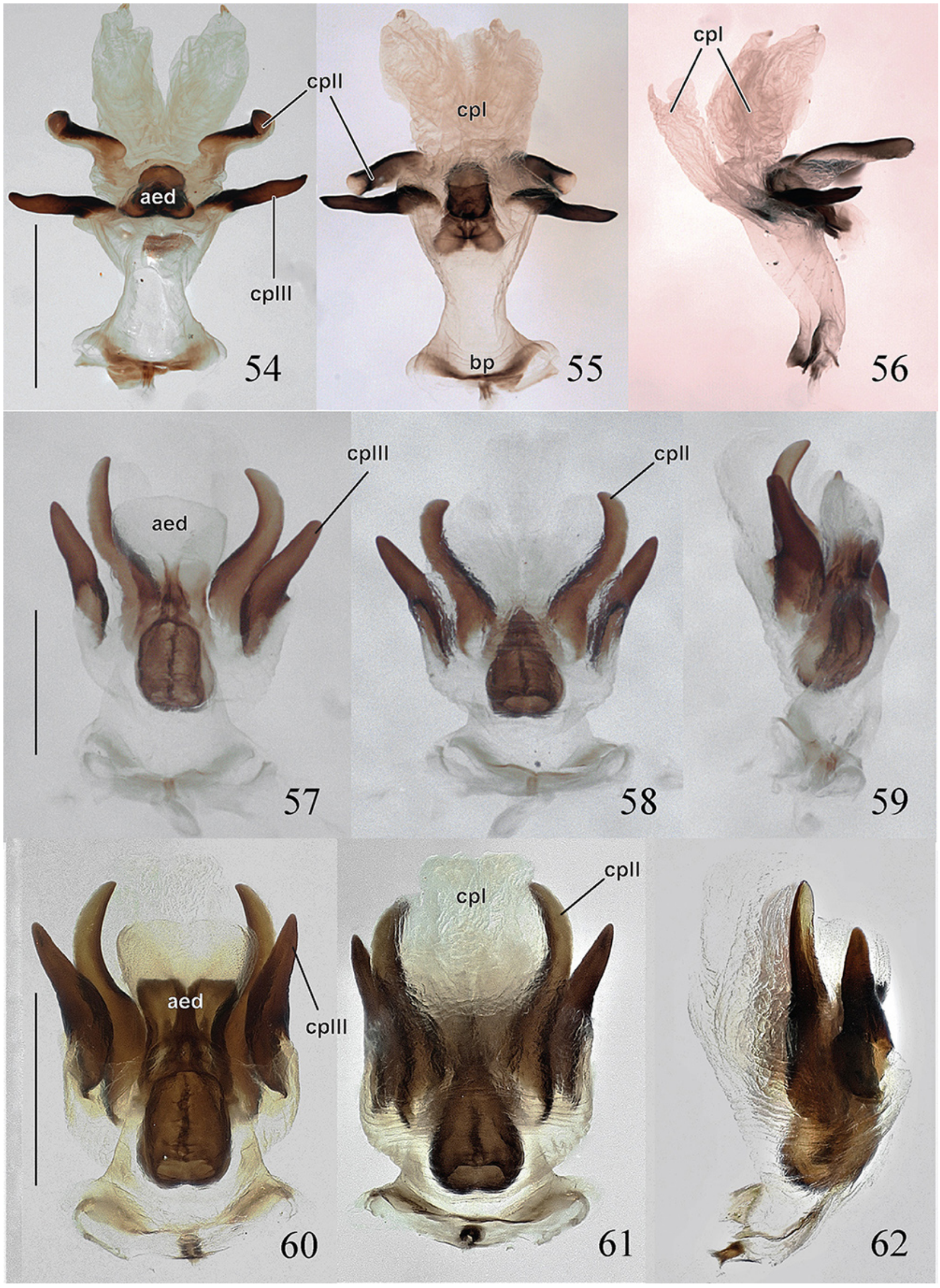

Figs 54-62. Coptochilus, phallus, respectively in ventral, dorsal, and lateral view: 54-56, C. castaneus (Dallas, 1851), reval.; 57-59, C. ferrugineus Amyot \& Serville, 1843; 60-62, C. lentiginosus Berg, 1879 (aed, aedeagus; bp, basal plate; cpI, conjunctival process I; cpII, conjunctival process II; cpIII, conjunctival process III). Scale bars: $0.5 \mathrm{~mm}$. 


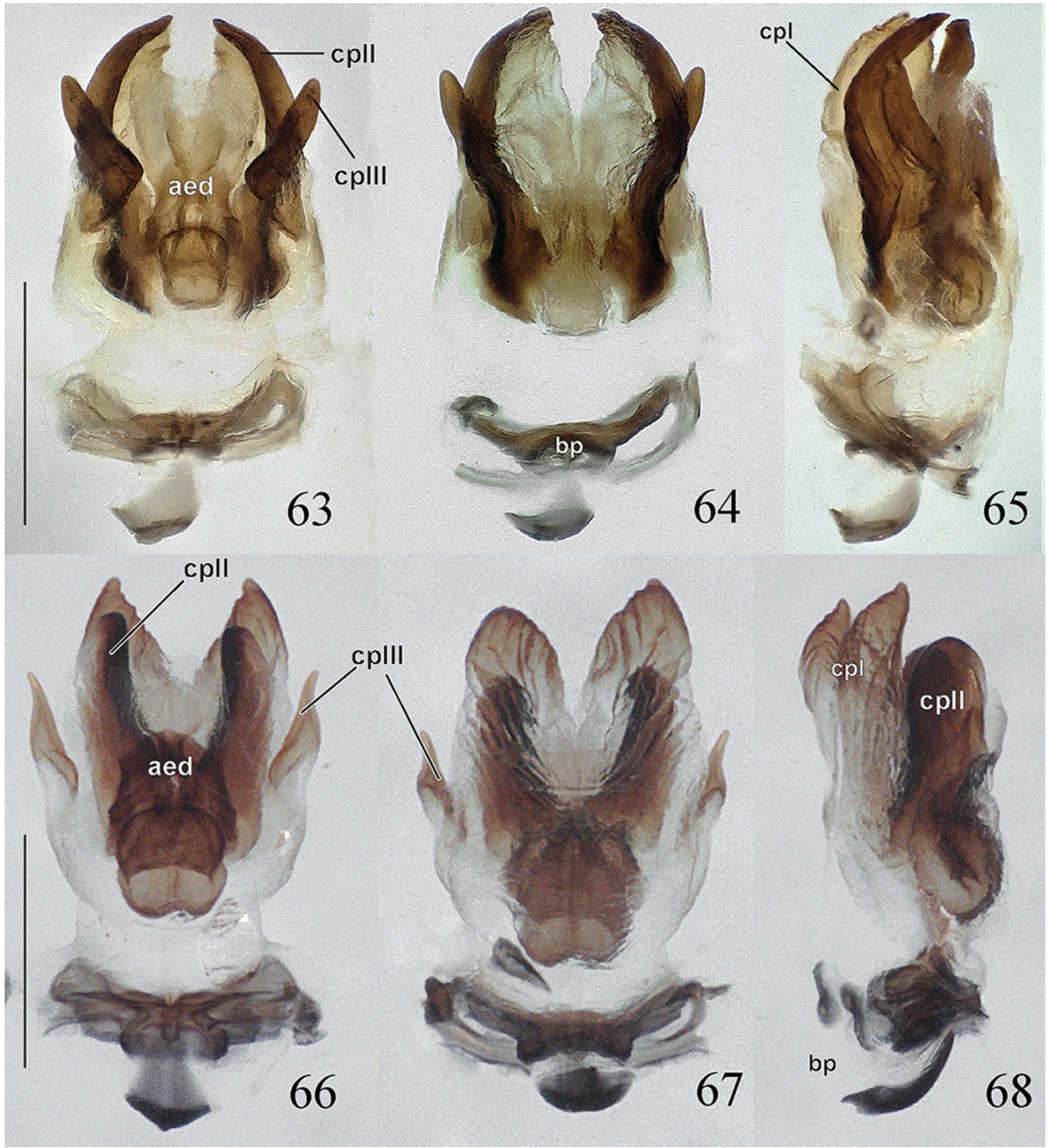

Figs 63-68. Coptochilus, phallus, respectively in ventral, dorsal and lateral view: 63-65, C. morrisi sp. nov.; 66-68, C. neotropicalis Distant, 1899. (aed, aedeagus; bp, basal plate; cpI, conjunctival process I; cpII, conjunctival process II; cpIII, conjunctival process III). Scale bars: $0.5 \mathrm{~mm}$.

\section{Coptochilus ferrugineus Amyot \& Serville, 1843}

(Figs 4-6, 19-21, 34-36, 47, 51-53, 57-59, $70,74,75,78,80)$

Coptochilus ferrugineus Амyot \& Serville, 1843:47 (description, type locality Brazil); DoHrn, 1859:4 (catalog); WALKER, 1867:53 (in part, catalog); STÅL, 1870:9 (in part, catalog, synonymy); BERG, 1879:26 (in part, distribution Argentina); LETHIERRY \& SEVERIN 1893:33 (in part, catalog); KirKaLdy, 1903:230 (in part, type of genus); Schouteden, 1904:92, 97 pl. 2, fig. 9 (in part, synonymy, illustration); KIRKALDY, 1909:283 (in part, catalog); PIRÁN, 1963:341 (distribution Argentina); CASAle, 1981:43 (list); Eger et al., 2015:761, 773, 782 (in part, distribution); CoSCARÓN, 2017:327 (distribution Argentina); WeILER et al., 2017:30-31, 35, fig. 11, 8a-f (external scent efferent system, illustration). 

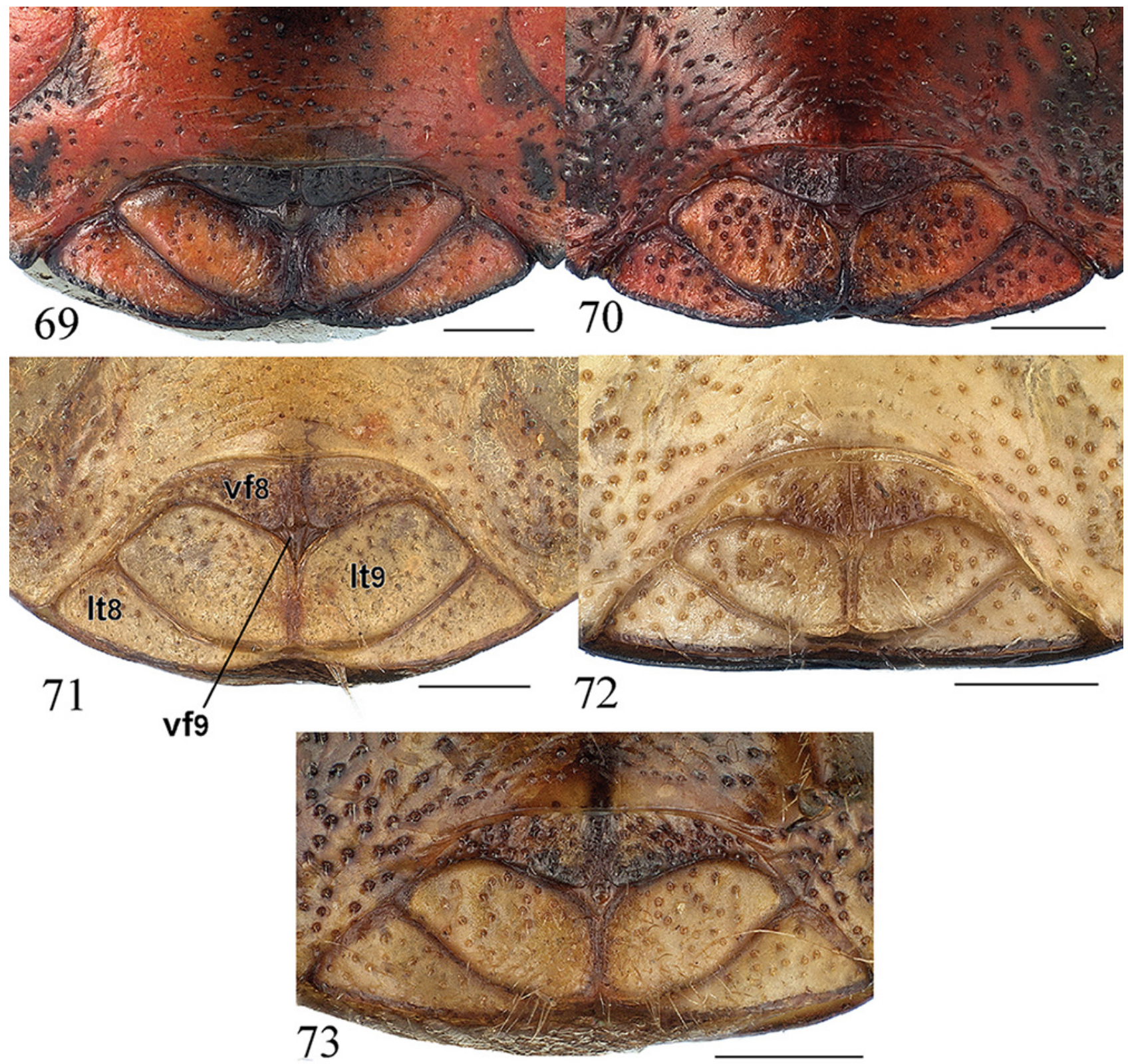

Figs 69-73. Coptochilus, genital plates: 69, C. castaneus (Dallas, 1851), reval.; 70, C. ferrugineus Amyot \& Serville, 1843; 71, C. lentiginosus Berg, 1879; 72, C. morrisi sp. nov.; 73, C. neotropicalis Distant, 1899 (1t8, laterotergites VIII; 1t9, laterotergites IX; vf8, valvifers VIII; vf9, valvifer IX). Scale bars: $0.5 \mathrm{~mm}$.

Medium-sized, dorsally ferruginous to red with relatively uniform black punctuations, venter dark red to black, punctation mostly concolorous with surrounding surfaces (Figs 4-6).

Head (Figs 19-21) dark yellow to red. Apex of mandibular plates rounded, subequal to or slightly surpassing clypeus, moderately elevated, clypeus and lateral margins of head darker than the remainder of head. Antennae dark red to black, first segment not usually lighter than remaining segments. Rostrum with segments light yellow to red, distal half or more of IV darker.

Pronotum with $2+2$ longitudinal darker stripes, these sometimes faded or unclear, anterolateral margins darker, straight to slightly concave. Scutellum uniformly dark yellow to red, punctation darker, lacking stripes or macules. Pleura mostly dark yellow or red or fully darker, lighter along inner and lateral margins, and pleural surfaces in the vicinity of the coxae and sterna. Legs. Dark yellow to light red on coxae, trochanters, and half or more of femora, remaining segments darker red to black.

Connexiva dark red, densely and concolorously punctate. Abdominal venter dark yellow to red laterally and lighter yellow to red mesially sometimes with darker stripes along the intersegmental sutures and pseudosutures; sternite VII in males and females slightly more than twice as long as VI medially (Fig. 5). 


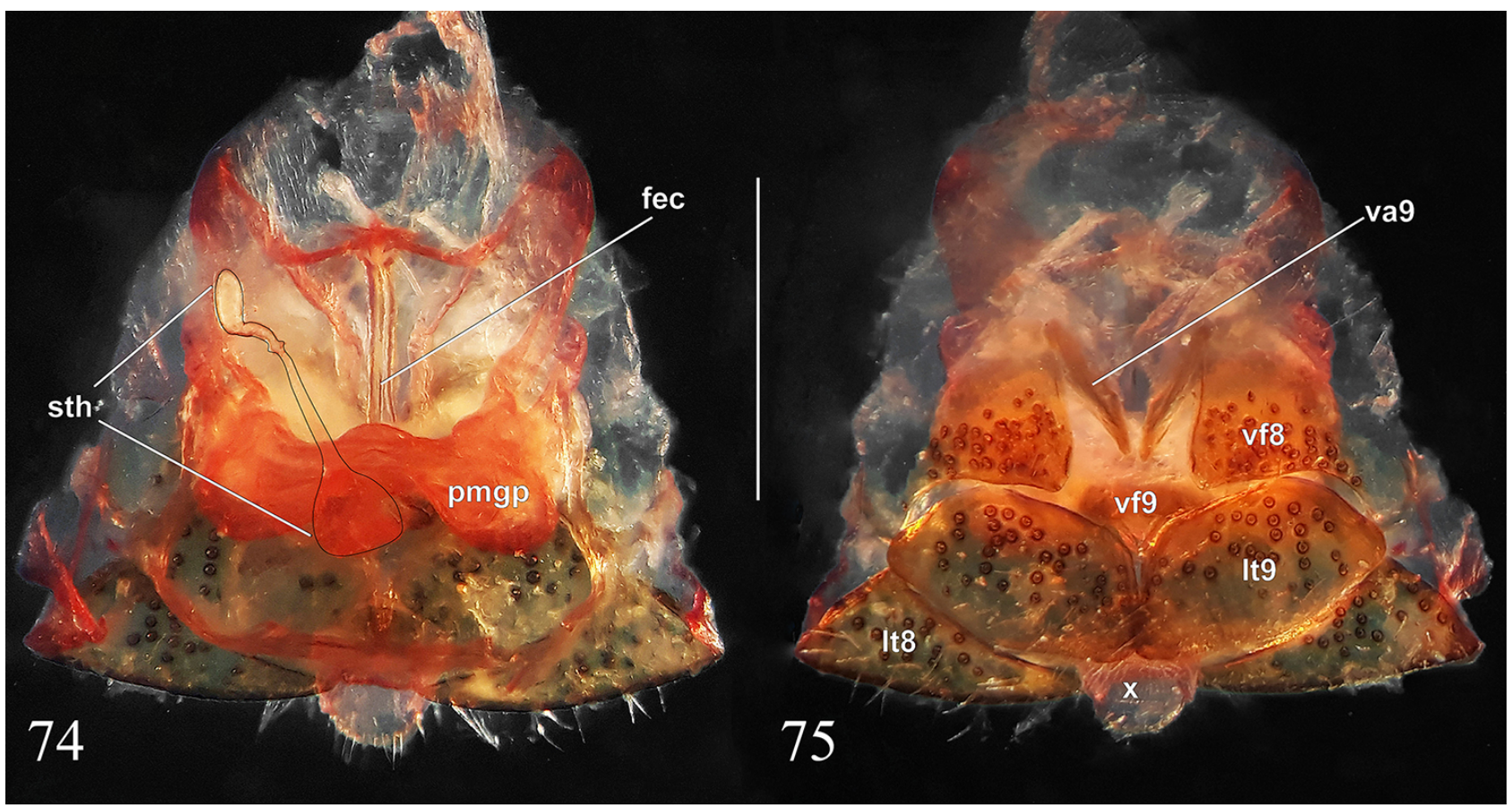

Figs 74-75. Coptochilus ferrugineus Amyot \& Serville, 1843, gynatrium: 74, dorsal view; 75,ventral view (fec, fecundatory canal; 1t8, laterotergites VIII; 1t9, laterotergites IX; pmgp, posteromedial genital pouch; sth, spermatheca; va9, valvulae IX; vf8, valvifers VIII; vf9, valvifer IX; X, proctiger). Scale bars: $1.0 \mathrm{~mm}$.
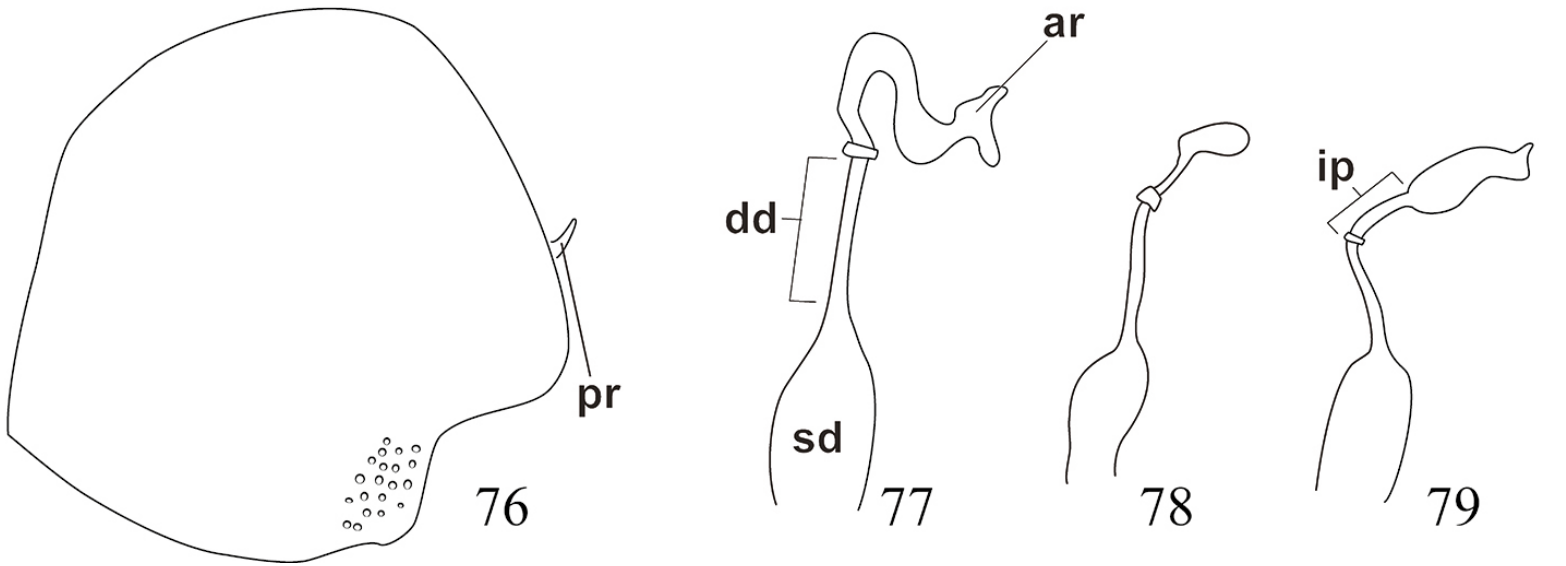

Figs 76-79. Coptochilus, schematic illustrations of genitalia: 76, C. lentiginosus Berg, 1879, pygophore in lateral view; 77-79 spermatheca, respectively: C. castaneus (Dalas, 1851), reval., C. ferrugineus Amyot \& Serville, 1843 and C. lentiginosus (ar, apical receptaculum; dd, distal duct; ip, intermediate part; pr, paramere; sd, spermathecal dilation). Scale bars: $1.0 \mathrm{~mm}$.

Male genitalia. Pygophore (Figs 34-36, 51-53). Ventral rim narrowly concave in the middle (Fig. 34), rectilinear in posterior view (Fig. 36). Head of parameres slightly curved, apex acute (Fig. 47). Phallus (Figs 51-53, 57-59). Conjunctival processes I surpassing conjunctival processes II and III, membranous, branched, ventral branch elongate, dorsal branch apically bilobed. Conjunctival processes II sclerotized, sickle-shaped, narrowly rounded to acute at apex, subequal in width as conjunctival processes III. Conjunctival processes III sclerotized, curved basally, relatively straight on apical $2 / 3$, almost as long as conjunctival processes II. Distal part of aedeagus rectilinear, converging to broadly rounded apex, with margins rounded.

Female genitalia (Figs 70, 74, 75, 78). Laterotergites IX subtrapezoidal, relatively broad, anterior margin markedly angled; valvifers VIII relatively narrow, posterior margin shallowly concave (Fig. 70). Spermatheca. Apical receptacle reniform, slightly longer than the intermediate part (Figs 74, 78).

Male measures $(\mathrm{mm})(\mathrm{N}=4)$. Total length $6.80-8.00$; head: length $1.75-1.90$, width $2.15-2.40$; length of anteocular region 1.00-1.75; pronotum: length 1.90-2.10, width 4.054.50; scutellum: length 3.95-4.60, width 3.70-4.20; length of sternite VI 0.05; length of sternite VII 1.10-1.20.

Female measures $(\mathrm{mm})(\mathrm{N}=8)$. Total length 6.35-9.00; head: length 1.80-2.00, width 2.40-2.70; length of anteocular region 1.00-1.20; pronotum: length 2.00-2.40, width 4.60 4.90; scutellum: length 4.60-5.50, width 4.10-4.60; length of sternite VI 0.50 ; length of sternite VII 1.10-1.25. 


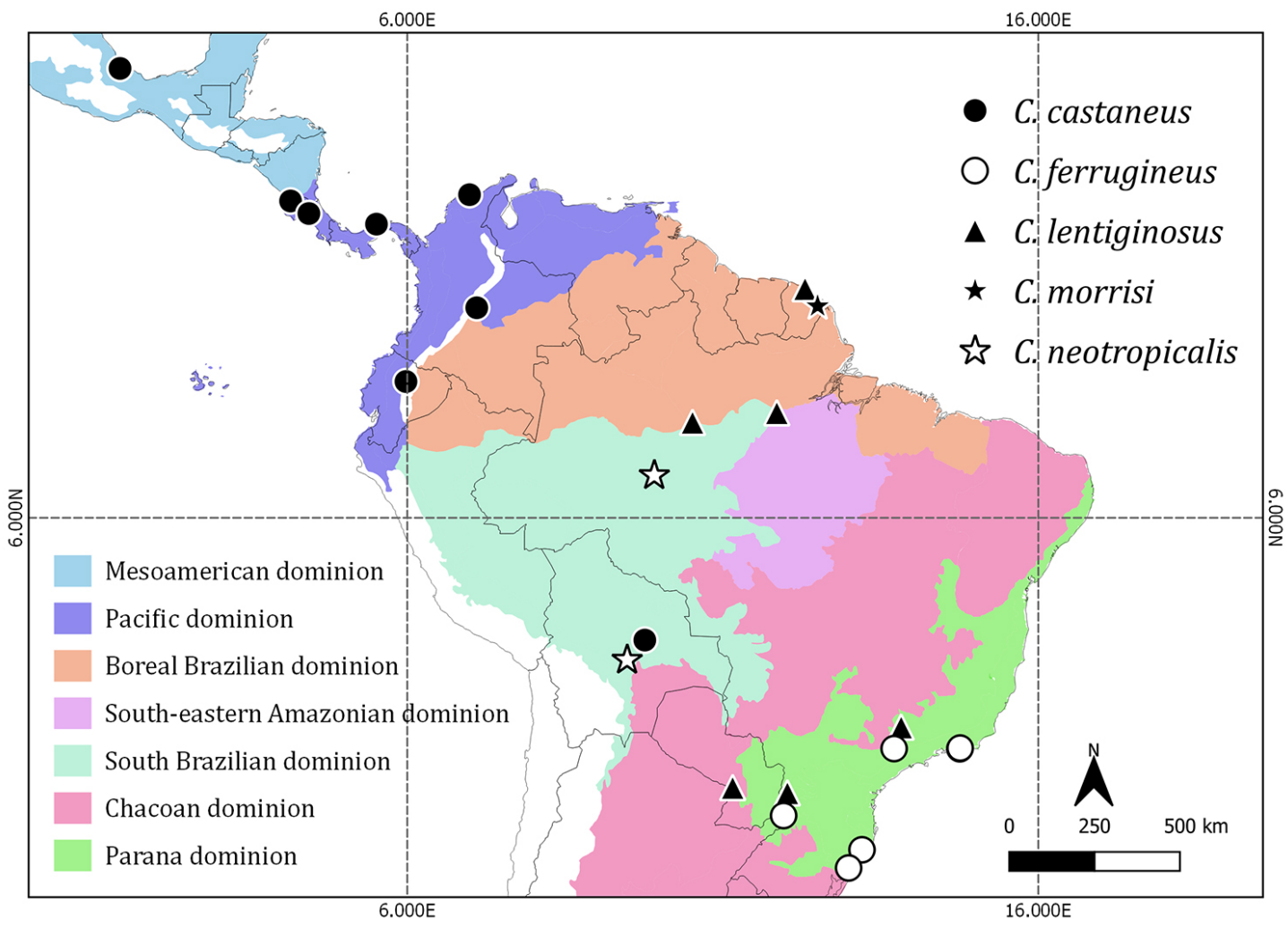

Fig. 80. Distribution of the species of Coptochilus, colored areas based on biogeographical dominions according to MORRONE (2013).

Type material. We could not find the type of Coptochilus ferrugineus, but the description (darker color, no mention of impunctate macules on pronotum) and the type locality leave little doubt of the identity of this species.

Material examined. BRAZIL, Coll. R. I. Sc. N. B., Bresil, + , ex. Coll. Schouteden (RBINS); São Paulo: (ca.

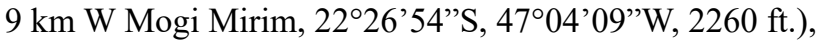
ô, 19.XII.2008, no collector (JEEC); Rio de Janeiro: no locality, + , XII.1931, O.F. (MCNZ 16422); Rio de Janeiro (Corcovado), + , III.1968, Alvarenga M. (AMNH_IZC 00319565); no locality, Ô, X, Acc. No. 2966 (CMNH); no locality, + , no date, Wygodzinsky P. (USNM); Santa Catarina: Criciúma (-28.70388, -4941587), 9,2008 , Bianchi F.M. (MCNZ s/n); Rio Grande do Sul: Maquiné (Est. Exp. Fepagro, Fogging - T7 lonas), $2 \widehat{\jmath}$, 25.IV.2006, Barcellos, A. (MCNZ 179780; 179781), 5 ㅇ, same data (MCNZ 179776$179778 ; 179782 ; 179783)$.

Distribution. Brazil and Argentina (Fig. 80).

Comments. EgER et al. (2015) also cited Bolivia and Ecuador in the distribution of C. ferrugineus, but these records refer to C. castaneus. Coptochilus ferrugineus is restricted to the Atlantic Rainforest [Paraná Dominion sensu Morrone (2013)].

Coptochilus lentiginosus Berg, 1879

(Figs 7-9, 22-24, 37-39, 48, 60-62, 71, 76, 79, 80)

Coptochilus lentiginosus BerG, 1879:26 (description, type locality Misiones, Argentina); Lethierry \& Severin, 1893:33 (catalog); Schouteden, 1904:46 (distribution); KIRKALDY 1909:283 (catalog); CosCARÓN \&
Froeschner, 2000:30-31 (type data); Coscarón et al., 2015:94, Figs 73K, 73N (type data, illustrations); EGER et al., 2015:761 (distribution); COSCARÓN \& RIDER, 2017:327 (distribution Argentina).

Medium-sized, light brown to dark yellow with irregular dark macules distributed primarily on pronotum and scutellum, black punctation relatively uniformly distributed on dorsum and laterally on the ventral surface (Figs 7-9).

Head (Figs 22-24) light brown to dark yellow with dark punctations, posterior and lateral margins of head and sometimes clypeus darker than the remaining surface of head. Mandibular plates acute to broadly rounded, surpassing but not converging in front of clypeus, apices moderately elevated (Fig. 22). Antenniferous tubercles and antennal segment I pale, segments II-V uniformly dark. Rostrum with segments light yellow, distal half or more of segment IV dark.

Pronotum yellowish with irregular circular black macules, punctation uniformly distributed, dark. Anterolateral margins straight to slightly concave or convex. Scutellum yellow with irregular circular black spots and uniformly distributed dark punctation. Pleura light to dark yellow or fully darker; middle of pleural segments and punctation usually darker; sterna yellow, punctation mostly darker than surrounding surfaces. Legs light yellow except for half or more of tibiae and tarsi dark.

Connexiva yellow with dense, darker punctation. Abdominal venter ranging from light yellow with almost concolorous punctation laterally to dark yellow with much darker areas along intersegmental sutures, and around spiracles; punctures in these areas, if present, usually darker 
brown. Sternite VII in females more than twice as long as sternite VI medially (Fig. 8); sternite VII in males about twice as long as sternite VI medially (1.92-2.18).

Male genitalia. Pygophore (Figs 37-39). Ventral rim uniformly concave (Fig. 37), slightly sinuous in posterior view (Fig. 39). Head of parameres slightly curved, apex acute (Fig. 48). Phallus (Figs 60-62). Conjunctival processes I surpassing conjunctival processes II and III, membranous, branched, ventral branch elongate, dorsal branch apically bilobed. Conjunctival processes II sclerotized, sickle-shaped, apices acute, subequal in width as conjunctival processes III; conjunctival processes III sclerotized, almost straight, and narrowly rounded apically almost as long as conjunctival processes II. Distal part of aedeagus dilated, somewhat bilobed with margins rounded.

Female genitalia (Figs 71, 79). Laterotergites IX subtrapezoidal, broad, anterior margin markedly angled; valvifers VIII broad mesially posterior margin strongly concave (Fig. 71). Spermatheca with apical receptacle subrectangular, 1.5 time longer than the intermediate part (Fig. 79).

Male measures $(\mathrm{mm})(\mathrm{N}=10)$. Total length 7.30-8.70; head: length $1.75-2.00$, width 2.25-2.60; length of anteocular region 1.00-1.20; pronotum: length 1.70-2.40, width 4.00 4.90; scutellum: length 4.10-4.90, width 4.10-4.50; length of sternite VI 0.55-0.60; length of sternite VII 1.15-1.20.

Female measures $(\mathrm{mm})(\mathrm{N}=10)$. total length 7.50 8.90; head: length 1.75-2.00, width 2.30-2.60; length of anteocular region 1.05-1.15; pronotum: length 2.00-2.55, width 4.10-4.95; scutellum: length 4.70-5.70, width 4.304.70 , length of sternite VI $0.45-0.55$; length of sternite VII 1.15-1.30.

Type material. Holotype female, labelled: a) Typus; b) Misiones [green label]; c) Coptochilus lentiginosus Berg; d) 1340 [rounded blue label] (MLPA) (examined by the second author).

Other material examined. FRENCH GUIANA, Cayenne: Rte. N1, 113 km SE Sinnamary, CIRAD Forest Reserve,, , 14.IV.1999, Edwards, G. B. (FSCA). BRAZIL, no data ,, , PRUhler Collection (USNM); Amazonas: Manaus, ㅇ, 6.III.1986, Aguiar N.O. (INPA); ㅇ, 17-22. III.1977, Ratcliffe B.C., H. D. Engleman Collection (JEEC); Pará: no locality, Ô, 17.I.1977, Overal, W.L. (MPEG); Santarém, + , no date, Acc. No. 2966 (CMNH); São Paulo: Campinas (6940, ex-col. IAC, Host. Cecropia sp.), 8ત̄, XII.1986, Rossetto, C.J. (IBSP 0.006.807, 0.006.816, $0.006 .813,0.006 .811,0.006 .815,0.006 .812,0.006 .809$, $0.006 .822,0.006 .819$ ), same data, 4 ㅇ (IBSP 0.006.814, 0.006.823, 0.006.818, 0.006.821); Piracicaba, + , no date, SAParLabo (USNM); Paraná: Iguaçu, đ̂, 29-28.X.[19]82, Gomez L., H. D. Engleman Collection (JEEC). PARAGUAY, Alto Paraná: (6 km W Puerto Presidente Stroessner), 4 $\overbrace{}^{\top}$, 12ㅇ, 25-28.I.[19]83, Riley E.G. (JEEC); Caaguazú (16 km E Coronel Oviedo), o, 29.I.[19]83, Riley E.G. (JEEC); Asunción, no locality, $\widehat{O}$, verano [summer], Podtiaguin B. (AMNH_IZC 00319566); Itapúa: [Capitán Miranda] (Hotel
Tirol), ○̂, 13-15.XII.2017, Eger, J. E. (IBNP). ARGENTINA, Misiones: Dos de Mayo, $\widehat{\jmath}$, XII.1992, no collector (JEEC).

Distribution. French Guiana, Brazil, Paraguay, and Argentina (Fig. 80).

Comments. Collected on Cecropia sp. (Urticaceae). Some specimens can be fully, or partially castaneous in the ventral or dorsal view. CosCARón et al. (2015) provided dorsal and lateral illustrations of the type specimen. However, figure 73L (p. 93) appears to be a lateral view of Tetyra poecila Berg and figure $73 \mathrm{~N}$ (p. 93) more closely resembles C. lentiginosus.

\section{Coptochilus morrisi Eger \& Schmitz sp. nov.}

(Figs 10-12, 25-27, 40-42, 49, 63-65, 72, 80)

urn:lsid:zoobank.org:act:C78D36CD-3EA5-4092-AFD97D12EA5FD91A

Coptochilus Neotropicsis EGER et al., 2015:761 (in part, typographical error, misidentification).

Type locality. French Guiana.

Relatively small compared with its congeners, yellowish-brown to orange, with six darker longitudinal stripes distributed on pronotum and scutellum; punctation moderately dense and mostly darker than surrounding surfaces. Venter uniformly light yellowish-brown to red, punctation less dense, unicolorous to clearly darker than the surrounding area (Figs 10-12).

Head (Figs 25-27). Pale yellow to red, with concolorous to dark brown punctation, clypeus and base of head darker than the remainder of head. Clypeus and mandibular plates strongly elevated anteriorly, mandibular plates converging at apex, their apices separated by about the width of second antennal segment or less (Fig. 25). Antennae pale basally, becoming darker apically, particularly segments IV and V. Rostrum light yellow or red, segment IV and sometimes part of segment III darker.

Pronotum yellow to red with dark to concolorous punctation and six longitudinal stripes. Each lateral stripe extending onto cicatrices anteriorly (not reaching anterior margin of pronotum), reaching posterior margin of pronotum and expanding laterally onto humeri; each intermediate stripe reaching from posterior to anterior margin of pronotum; middle pair of stripes narrower than the other two, also not reaching anterior pronotal margin and separated from each other by pale impunctate line. Anterolateral margins of pronotum straight to shallowly convex. Scutellum similar in color to pronotum, six stripes originating at the anterior margin and extending posteriad for about $2 / 3$ length of scutellum, then coalescing into a broad dark area on about posterior $1 / 3$ of scutellum. Legs immaculate, concolorous with the remainder of venter.

Connexiva pale and uniformly colored, with shallow moderately dense punctation laterally, this usually darker than the rest of connexiva. Venter light yellow to red with unicolorous to slightly darker punctation. Sternite VII in females twice as long as sternite VI, almost twice as long in males. 
Male genitalia. Pygophore (Figs 40-42). Ventral rim evenly concave (Figs 40,41), slightly sinuous in posterior view (Fig. 42). Head of parameres curved, apex rounded (Fig. 49). Phallus (unexpanded) (Figs 63-65). Conjunctival processes I surpassing conjunctival processes III, broad, appearing somewhat sclerotized apically; conjunctival processes II sickle-shaped, thin, mostly sclerotized, extending apically as far as conjunctival processes I, a little broader than conjunctival processes II; conjunctival processes III right-angled, rounded at apex, half as long as conjunctival processes II. Distal part of aedeagus dilated with margins rounded.

Female genitalia (Fig. 72). Laterotergites IX sub trapezoidal, narrowed laterally, anterior margin convex. Valvifers 8 relatively broad, posterior margins shallowly concave (Fig. 72).

Male measurements ( $\mathrm{n}=5$ ). Total length 6.60-7.05; head: length 1.50-1.75, width 2.20-2.35; length of anteocular region $0.90-1.00$; pronotum: length $1.90-2.30$, width $3.85-$ 4.10; scutellum: length 3.80-4.30, width 3.65-4.00; median length of sternites VI-VII: $0.50-0.55,0.85-1.00$.

Female measurements $(\mathrm{n}=1)$. total length 7.20 ; head: length 1.80, width 2.40; length of anteocular region 1.00; pronotum: length 2.25 , width 4.20 ; scutellum: length 4.50 , width 4.05, median length of sternites VI-VII:0.45, 0.90;

Type material. Holotype $\delta^{\lambda}$ : a) FRENCH GUIANA, Amazone Nature Lodge, Kaw Rd. 6, IX/1-12/2018, Morris \& Wappes; b) N04³3.579' W052 ${ }^{\circ} 12.433$ ', Elev. 977', MV Light (JEE, deposited in USNM). Paratypes: $\widehat{\partial}$,, same data as holotype ( $\widehat{\partial} \mathrm{JEE}, \phi$ JEE deposited in USNM); $\hat{\partial}$, same data as holotype except for VI/19-31/2019 (JEE deposited in FSCA); ${ }^{\Uparrow}$ a) FR. GUIANA, Hwy ext. N1, $20 \mathrm{~km} \mathrm{SE}$ of St. Larent, 7-VI-1986, E. G. Riley \& D. A. Rider; b) collected at mercury vapor (DAR); $\widehat{\partial}$ a) FRENCH GUIANA: $17 \mathrm{~km} \mathrm{~W}$ of N2 on Belizon Rd., 3-XII-2002, J. E. Eger; b) N04 $17.825^{\text {' }}$ W052 22.218', 94 m, MV Light (JEE).

Distribution. French Guiana (Fig. 80).

Etymology. This species is named for Roy Morris, a friend and colleague who collected the holotype and three of the five paratypes.

Comments. This species resembles C. neotropicalis in having the pronotum and scutellum striped. It was misidentified as $C$. neotropicalis from French Guiana by EGER et al. (2015). It differs from that species by the mandibular plates converging apically with only a small space between them and by the male internal genitalia. One male specimen has dark punctation ventrally on head and thorax and the abdomen completely black ventrally except for a narrow pale band laterally and posteriorly. This may be a result of discoloration, but it appears to be natural coloration. We were not able to obtain fully expanded male internal genitalia and opted not to dissect the single female paratype.
Coptochilus neotropicalis Distant, 1899

(Figs 13-15, 28-30, 43-45, 50, 66-68, 73, 80)

Achates neotropicalis Distant, 1899:42 (description, type locality Brazil (Madeira River).

Chelyschema neotropicalis; SCHOUTEDEN, 1904:47 (synonymy); KIRKALDY, 1909:283 (catalog).

Coptochilus neotropicalis; EGER \& LATTIN, 1997:417 (synonymy, type). Coptochilus Neotropicsis EGER et al., 2015:761 (in part, typographical error, distribution).

Type locality: Amazonas, Brazil (region of Madeira river).

General color yellow to red, with six darker longitudinal stripes distributed on pronotum and scutellum, punctation dark brown to black. Venter dark yellow to castaneus, punctation concolorous to darker than surrounding surfaces (Figs 13-15).

Head (Figs 28-30). Yellow to red, darker along posterior margin and clypeus, and sometimes laterally on mandibular plates. Mandibular plates subequal in length to clypeus, slightly elevated, apices acute to narrowly rounded, not converging in front of clypeus, separated by much more than the diameter of second antennal segment (Fig. 28).

Pronotum yellow to red, punctation dark, anterolateral margins straight to slightly convex. Each lateral stripe extending onto cicatrices anteriorly but not reaching anterior margin of pronotum, reaching posterior margin of pronotum but not extending laterally on to humeri which are generally provided with small black macule; each intermediate stripe extending from posterior to anterior margin of pronotum; middle pair of stripes narrower than and shorter than other two pairs, also not reaching anterior margin of pronotum and separated by a thin impunctate line. Scutellum yellow to red with six darker lines extending from anterior margin to about $2 / 3$ of distance to posterior margin, not coalescing posteriorly. Pleura dark red to black mesially, lateral margins and area around coxae lighter colored. Legs pale basally becoming darker distally on femora, and on tibiae and tarsi.

Abdomen dark yellow to black, punctation dark, concolorous on darker surfaces; connexiva pale, densely and darkly punctate. Sternite VII in females slightly more than twice as long as sternite VI medially, sternite VII in males less than or equal to twice as long as sternite VI (Fig. 14).

Male genitalia. Pygophore (Figs 43-45). Ventral rim slightly sinuous (Fig. 43), almost rectilinear in posterior view (Fig. 45). Head of parameres curved, apex rounded (Fig. 50). Phallus (Figs 66-68). Conjunctival processes I surpassing conjunctival processes II and III, membranous basally, somewhat sclerotized apically; conjunctival processes II slightly curved, enlarged, apex broadly rounded, broader than conjunctival processes III. Conjunctival processes III thin, membranous basally, apices acute and lightly sclerotized, half as long as conjunctival processes II. Distal part of aedeagus sensu stricto dilated somewhat bilobed basally.

Female genitalia (Fig. 73). Laterotergites IX subtrapezoidal, anterior margin rounded; laterotergites VIII 
relatively broad; valvifers III moderately broad, posterior margins shallowly concave (Fig. 73).

Male measures $(\mathrm{mm})(\mathrm{n}=3)$. Total length 7.00-7.20; head: length 1.60-1.70, width 2.30-2.35; length of anteocular region $0.80-0.90$; pronotum: length $2.10-2.20$, width $4.15-$ 4.20; scutellum: length 4.20-4.40, width 4.00-4.10; length of sternites VI and VII 0.50-0.60, 1.00-1.10.

Female measures $(\mathrm{mm})(\mathrm{n}=1)$. Total length 7.30; head: length 1.70 , width 2.30 ; length of anteocular region 0.90 ; pronotum: length 2.25 , width 4.20 ; ventral length of sternites VI and VII 0.50, 1.10.

Type material. Holotype male, labeled: a) Type [red circle] b) Madeira R.; Amazon, c) Distant Coll., 1911-383, d) neotropicalis Distant, e) BRIT. MUS. TYPE No. HEM. 55 (examined by the third author).

Other material examined. BRAZIL, Amazonas: Maturacá (Rio Negro), ô, 22.I.1953, Bechyné B. \& J. (MCNZ). BOLIVIA, Santa Cruz: Buena Vista (Flora \& Fauna Hotel), $\widehat{\jmath}$, ㅇ, 14-26.XI.2002, Morris, Nearns \&Wappes (JEEC); 2へ, 22-26.X.2002, Morris \&Wappes (JEEC).

Distribution. Brazil (Amazonas) and Bolivia (Fig. 80).

Comments. The type specimen has the intermediate stripes on the scutellum broken near the anterior margin of scutellum and a similar break near the posterior extremity of the lateral stripes. We opted not to dissect the single female specimen available to us.

Acknowledgments. To Dr. Talita Roell for the photos of BMNH types and MSc. Wanessa da Silva Costa for assembling some specimens. We would like to express our thanks to the curators of collections noted previously for the loan of specimens used in this study.

\section{REFERENCES}

Amyot, C. J. B. \& Serville, J. G. A. 1843. Histoire Naturelle des Insectes. Hémiptères. Paris, Librairie Encyclopédique de Roret. 676p.

Becker, M. \& Grazia-VieIRA, J. 1977. The Pentatomoidea (Heteroptera) collected in French Guiana by the expedition of the Muséum National d'Histoire Naturelle. Annales de la Societé Entomologique Française 13:53-67.

BERG, C. 1879. Hemiptera argentina enumeravit speciesque novas descripsit. Buenos Aires, Pauli E. Coni. 204p.

Casale, A. 1981. Cataloghi II - Collezione Emitterologica di Massimiliano Spinola. Torino, Museo Regionale di Scienze Naturali. 120p.

Coscarón, M. C. 2017. A catalogue of the Heteroptera (Hemiptera) or true bugs of Argentina. Zootaxa 4295(1):1-432. https://doi.org/10.11646/ zootaxa.4295.1.1

Coscarón, M. C. \& Froeschner, R. 2000. Los ejemplarestipo de Cydnidae, Scutelleridae y Thyreocoridae (Heteroptera) depositadosen el Museo de La Plata. Revista del Museo La Plata, Serie Técnica y Didáctica, 37:29-32

Coscarón, M. C.; Basset, C. \& Lopez, N. 2015. Types of true bugs (Insecta, Hemiptera, Heteroptera) deposited in the Museo de La Plata, Argentina. Zootaxa 3977(1):1-101. https://doi.org/10.11646/zootaxa.3977.1.1
Dallas, W. S. 1851. List of the specimens of hemipterous insects in the collection of the British Museum. London, British Museum. Part 1, 368p.

Dallas, W. S. 1864. Insecta. In: Günther, A. C. L. G. ed. The record of zoological literature. London, Taylor \& Francis, p. 328-589.

Distant, W. L. 1899.Rhynchotal notes-Heteroptera: Scutellerinae and Graphosominae. Annals of the Magazine of Natural History 4(7):29-52.

DoHrn, A. 1859.Catalogus Hemipterorum. Stettin, Herrcke and Lebeling. $112 \mathrm{p}$.

Eger, J. E. \& Lattin, J. D. 1997. Generic placement and synonymy of some New World Scutelleridae (Hemiptera, Heteroptera) in the British Museum (Natural History). Journal of the New York Entomological Society 103(4):412-420.

Eger Jr., J. E.; BArcellos, A. \& Weiler, L. 2015. Shield bugs (Scutelleridae). In: Panizzi, A. R. \& Grazia J. eds. True Bugs (Heteroptera) of the Neotropics. New York, Springer, p.757-788.

Grazia, J. \& Schwertner, C. F. 2011. Check-list dos percevejos-do-mato (Hemiptera: Heteroptera: Pentatomoidea) do Estado de São Paulo, Brasil. Biota Neotropica 11(1a):1-12.

Handlirsch, A. 1900. Zur Kenntniss des Stridulationsorgane bei den Rhynchoten. Annalen des K. K. Naturhistorischen Hofmuseums 15:127-141.

KIRKALDY, G. W. 1903. On the nomenclature of the genera of the Rhynchota; Heteroptera and Auchenorrhynchous Homoptera. The Entomologist 36(484):230-233.

Kirkaldy, G. W. 1909. Catalogue of the Hemiptera (Heteroptera) with biological and anatomical references, list of food plants and parasites, etc. Berlin, Felix L. Dames. v 1, Cimicidae. 392p.

Lethierry, L. \& Severin, G. 1893. Catalogue General des Hémiptères. Tome I. Hétéroptères Pentatomidae. Bruxelles, F. Hayez. 286p.

LöwenberG, P. 2014. Neotropical region: a shapefile of Morrone's biogeographical regionalisation. Zootaxa 3802(2):300.

MAYR, G. L. 1868. Hemiptera. In: Reise der Österreichischen Freggate Novara um die Erde in den Jahren 1857, 1858, 1859. Zoologischer Teil, II, Abt. 1. 204p.

Morrone, J. J. 2013. Cladistic biogeography of the Neotropical region: identifying the main events in the diversification of the terrestrial biota. Cladistics 30(2):202-214.

PIRÁN, A. A. 1963. Hemiptera Neotropica VII. Algunas especies nuevas o poco conocidas del noroeste argentino I. Acta Zoologica Lilloana 19:335-341.

Schouteden, H. 1904. Heteroptera. Fam. Pentatomidae. Subfam. Scutellerinae. Genera Insectorum 24:1-98.

STÅL, C. 1864. Hemiptera Mexicana enumeravit speciesque novas descripsit. Stettiner Entomologische Zeitung 25:49-86.

STÅL, C. 1867. Bidrag till hemipterernas systematic. Öfvers Kongliga Vetensk Akademie Förhandligar 24:491-560.

STÅL, C. 1870. Enumeratio Hemipterorum. Bidrag till en företeckning öfver alla hittils kända Hemiptera, jemte systematiska meddelanden. 1. Kongliga Svenska Vetenska-Akademie Handligar 9(1):1-232.

Tsai, J. F.; RéDeI, D.; Yeh, G. F. \& YANG, M. M. 2011. Jewel bugs of Taiwan (Heteroptera: Scutelleridae). Taichung, National Chung Hsing University. 309p.

WALKER, F. 1867. Catalogue of the specimens of heteropterous-Hemiptera in the collection of the British Museum. London, British Museum. Part 1, p. 1-240.

Weber, H. 1930. Biologie der Hemipteren eine Naturgeschichte der Schnabelkerfe. Berlin, Julius Springer. 543p.

Weiler, L.; BarÃo, K. R.; CASSIS, G. \& GraZIA, J. 2017. Morphology of the external scent efferent system of Neotropical shield bugs (Hemiptera: Scutelleridae: Pachycorinae). Zoomorphology 136:29-44. 